\section{Modos de orientação na floresta e as formas do entender no extrativismo comercial da castanha entre quilombolas do Alto Trombetas, Oriximiná/PA}

Igor Alexandre Badolato Scaramuzzi

Universidade de Campinas / Campinas, SP, Brasil

igorabs@hotmail.com | https://orcid.org/0000-0002-4654-1393
Dol

http://dx.doi.org/10.11606/ 2179-0892.ra.2020.168623

RESUMO

Os quilombolas do Alto Trombetas, município de Oriximiná/PA, desde o tempo que Conhecimento, se estabeleceram nesta região no início do séc. XIX até os dias de hoje, têm o extrativismo comercial da castanha como a principal modalidade de intercâmbio comercial desenvolvida com os diversos segmentos regionais que habitavam e habitam a região. Atualmente, os castanhais localizados no território dos quilombolas são de usufruto coletivo e para evitar a concorrência muitos extrativistas, por meio da restrição da transmissão de certos saberes relacionados ao ramo castanheiro, buscam a exclusividade de uso de fragmentos específicos destas florestas. Este artigo busca, por meio da descrição e análise etnográfica de algumas habilidades constituintes do ramo castanheiro, especialmente dos modos de orientação na floresta, demonstrar como os saberes expressos pelo conceito local de entender se produzem e se atualizam nesta atividade.

Orientation in the Forest and Forms of Knowing (Entender) in the Commercial Extractivism of Brazil Nuts Among Quilombolas in Alto Trombetas, Oriximiná, State of Pará, Brazil

ABSTRACT Brazil nut extractivism has been the main commercial activity for the Quilombola communities of Alto Trombetas, since their arrival in the region, in the beginning of the 19th century, until today. Currently, Brazil nut trees within Quilombola territories are communal property and to avoid competition, extractivists are very careful with the transmission of their knowledge, while often attempting to keep a specific fragments of the forest for their exclusive use. This article explores ethnographically some of the skills necessary for Brazil nut extractivism, particularly the ways of orienting oneself in the forest, by showing how the knowledge expressed by the local concept of entender is produced and constantly renewed.

\section{KEYWORDS}

Knowledge, Amazon,

Guidance, Quilombolas, Nature 


\section{INTRODUÇÃO}

Este artigo resulta da descrição e análise etnográfica do extrativismo comercial da castanha realizada em minha tese de doutorado (Scaramuzzi, 2016) entre os quilombolas do Alto rio Trombetas, situados no município de Oriximiná, no norte do estado do Pará'. As comunidades quilombolas do município de Oriximiná/PA são constituídas pelos descendentes de escravos que no século XIX fugiram das fazendas e das propriedades que exploravam o cacau e a pecuária nas regiões dos atuais municípios de Óbidos, Santarém, Alenquer e Belém. Neste tempo, se estabeleceram nos trechos encachoeirados dos rios Trombetas, Cuminá e Erepecuru (Andrade, 1995)².

Pode-se dizer que, desde a formação dos quilombos na bacia do rio Trombetas até os dias de hoje, o extrativismo comercial da castanha do Pará, castanha do Brasil ou castanha da Amazônia é a principal modalidade de intercâmbio comercial praticada pela população quilombola com os diversos segmentos regionais que habitavam e habitam atualmente a região. As fontes escritas e orais sobre a história quilombola na região do Alto Trombetas salientam que as atividades extrativistas foram fundamentais para, por um lado, garantir a autonomia econômica desta população no tempo da escravidão e, por outro, assegurar a continuidade da ocupação do mesmo território até os dias de hoje 3 .

Nativa da Amazônia, a castanheira (Bertholletia excelsa) é uma árvore de grande porte e longevidade que se encontra distribuída de forma descontínua em todo bioma amazônico, notadamente em florestas de terra firme. Ceralmente, as castanheiras habitam ambientes com alta densidade populacional de sua espécie, lugares que são conhecidos tanto na literatura científica, quanto pelos quilombolas, como castanhais4. Os castanhais têm como característica principal a presença em espaços circunscritos de grandes aglomerados populacionais de castanheiras dominando o dossel da floresta. As sementes das castanheiras, as castanhas, são abrigadas em fruto lenhoso chamado de ouriço, são altamente nutritivas, de agradável sabor e muito apreciadas no mercado internacional e nacional. A coleta da castanha é realizada quando os ouriços ficam maduros e caem ao chão. Sabe-se que as castanheiras são manejadas por populações indígenas desde os tempos pré-colombianos e que sua comercialização em grande escala ocorre desde o séc. XIX (Ramires \& Shepard, 2011).

No Alto Trombetas, as castanheiras, embora tenham certas preferências, vivem em vários tipos de ambiente: nas várzeas, na mata bruta, nas baixas, nas ilhas, em lugares muito próximos ou muito distantes das águas 5 . Na porção do território quilombola no Alto Trombetas, a região da margem esquerda - em sobreposição com a Reserva Biológica do rio Trombetas - é aquela onde há a maior população de castanheiras. Na margem direita, com exceção do entorno das áreas habitadas e das margens dos grandes lagos, não há a ocorrência abundante de castanha. As áreas de castanhais do território dos quilombolas são muito extensas, formando

1 Minha tese de doutorado "Extrativismo e as Relações com a Natureza em Comunidades Quilombolas do Rio Trombetas/Oriximiná/Pará" foi orientada pela professora Nádia Farage e defendida na Universidade Estadual de Campinas/Unicamp em 2016 $A$ pesquisa foi financiada pela agência FAPESP - Fundação de Amparo à Pesquisa do Estado de São Paulo.

2 | A formação dos mocambos ou quilombos na bacia do rio Trombetas foi documentada através de uma série de fontes históricas escritas que foram analisadas na tese de doutorado (1995) e em uma série de artigos posteriores $(1999,2004,2007,2009)$ do historiador Eurípedes Funes; no livro a respeito da escravidão e formação dos quilombos na região, de Acevedo \& Castro (1998) e em trabalhos que tratam da história da escravidão na Amazônia e no estado do Pará de forma mais genérica como Salles (1988).

3| O extrativismo comercial da castanha se tornou um importante elemento constituinte do modo de ser e viver desta população que é usado nos contextos de negociação com segmentos estatais para a distinção sociológica em relação à população rural e ribeirinha habitantes da mesma região. O termo extrativismo, como salienta Almeida (2012: 125), pode ser associado a um tipo de economia florestal predatória, ligada a relações sociais de dependência e dominação dos tempos em que os produtos florestais amazônicos estavam em alta no mercado internacional, na primeira metade do século 
um continuum de milhares de hectares que interliga diversos aglomerados populacionais da espécie.

Além de castanhal, os extrativistas possuem outros termos para designar coletivos de castanheiras. O mais usado pelos castanheiros com os quais realizei minha pesquisa de campo é ponta de castanha. Pontas de castanha são porções de terra circunscritas, geralmente de pequena extensão em comparação aos espaços que chamam de castanhais, povoadas quase em sua totalidade por castanheiras. As pontas de castanha são as unidades de manejo onde o conhecimento sobre o ambiente do castanhal se desenvolve no âmbito da atividade extrativista ou, de acordo com alguns castanheiros, onde se desenvolve o entender sobre as matas de castanhal.

Atualmente, no Alto Trombetas os castanhais são de usufruto coletivo e, para evitar a concorrência, muitos extrativistas prezam, através da restrição da transmissão de certos saberes, pela exclusividade de uso de fragmentos florestais específicos nos locais em que trabalham e circulam. Boa parte dos saberes que embasam os modos de conhecer dos quilombolas relacionados ao ramo castanheiro foram assinalados por meus interlocutores através do conceito local denominado entender. Entender uma mata de castanhal se faz pela prática contínua e por um longo tempo da coleta da castanha em escala comercial e das atividades paralelas como a caça, a pesca e a coleta de outros gêneros vegetais nos mesmos fragmentos florestais. Através da descrição e análise etnográfica de algumas habilidades constituintes do ramo castanheiro, especialmente dos modos de orientação na floresta, pretendo demonstrar como os saberes expressos pelo conceito de entender se produzem e se atualizam nesta atividade.

\section{MODOS DE SE RELACIONAR E CONHECER OS AMBIENTES}

A discussão proposta neste artigo visa contribuir para o debate na antropologia sobre os modos como as pessoas conhecem os ambientes onde vivem e com os quais se relacionam. Uma questão importante deste debate na disciplina e que pretendo dar enfoque no que segue é a que problematiza a relação entre a prática/processos e mente/ cognição na produção e atualização dos conhecimentos relacionados ao ambiente.

$\mathrm{Na}$ literatura antropológica, este debate está sintetizado por Ingold (2005) que, em um ensaio profundo e detalhado, distingue duas linhas teóricas e analíticas que abordam esta relação.

A primeira é denominada por ele de "cognitivista". Ela parte do pressuposto de que os conhecimentos ambientais estão inscritos nas paisagens e nos seres vivos que compõem os ambientes. A experiência e a relação contínua com o meio permitem aos humanos a identificação e a memorização destes elementos que são sistematizados na mente em forma de "mapas cognitivos". Ela está representada no ensaio de Ingold pela abordagem de Alfred Cell (1985) dedicada ao tema
XX. Pode também, tal como é usado pelo autor e adotado na descrição etnográfica do extrativismo da castanha que desenvolvi em minha tese de doutorado (Scaramuzzi, 2016), estar associado a um modo de vida florestal no qual a venda de produtos florestais, como a castanha, é uma das atividades que está integrada a um sistema amplo de atividades, que conformam usos e ocupações territoriais de "baixo impacto ambiental" e que viabilizam, em um tempo de longa duração, a existência, a dignidade e a convivência das populações humanas com uma grande diversidade de vida. Creio que as populações quilombolas da bacia do rio Trombetas se encaixam nessa acepção, pois habitam, há mais de 200 anos, em boa convivência, uma das regiões amazônicas mais preservadas do país. Desse modo, além do fato de serem comunidades remanescentes de quilombos, o que lhes garante constitucionalmente o direito às terras tradicionalmente ocupadas, a atividade extrativista, seguida do fato de também se identificarem como "castanheiros, compõem a produção discursiva enunciada em diversos contextos para justificar, perante os segmentos do Estado Nacional, seus direitos territoriais.

4 | Os termos locais mais relevantes à descrição proposta no artigo estão grafados em itálico. Em razão de conflitos existentes com uma unidade de conservação de proteção integral - a Reserva Biológica do Rio Trombetas/REBIO Trombetas - optei por não divulgar as identidades de meus interlocutores.

5| A taxonomia dos ambientes dos quilombolas não será 
da orientação e do conhecimento ambiental na navegação entre marinheiros indígenas da Micronésia.

A segunda, denominada por ele de "processualista", inclui sua própria abordagem analítica da questão. Esta parte do pressuposto de que o conhecimento não se sistematiza como um conteúdo mental e não consiste somente na aquisição de saberes fisicamente localizáveis que estão inscritos no meio, como elementos externos a serem identificados e sistematizados na cognição. O conhecimento se realiza e permanece conectado nas próprias relações dos humanos com o ambiente, não se armazena em um "sistema cognitivo" e não possui uma existência "externa" a tais processos.

O ponto principal de discordância levantado por Ingold entre as duas abordagens consiste basicamente na questão de saber se o conhecimento sobre o ambiente pode ou não existir "fora" de seus contextos e dos locais onde são produzidos e se podem, portanto, existir ou não como um "conteúdo mental". Há, no meu entender, nas formulações de Ingold, mais precisamente em seu ensaio denominado "Da transmissão de representações à educação da atenção" (2010:18), um aspecto fundamental que assinala tal discordância, que é a distinção entre conhecimento e informação. Os elementos fisicamente localizáveis, que na abordagem de Alfred Gell podem ser sistematizados na memória, situados e transmitidos fora dos contextos onde são apreendidos, são na visão ingoldiana "informação". Com efeito, a transmissão fora dos contextos e dos locais de produção do conhecimento - na abordagem de Ingold - é um aspecto muito importante para o movimento e um caminho para o conhecimento, mas ela não veicula em si o conhecimento, pois como salientado este não pode ser desvinculado de seus locais e de seus processos de produção (idem).

Como procurarei demonstrar a seguir, a análise do conceito quilombola de entender possui pontos de concordância e de semelhança com as duas abordagens e evidencia que a produção e atualização dos conhecimentos sobre o ambiente não operam necessariamente segundo esta distinção ingoldiana. O conceito de entender, para os meus interlocutores é concretizado e atualizado nas experiências nas matas e pela execução frequente e repetitiva das atividades e das práticas que compõem o ramo extrativista, tal como ilustra Ingold pela abordagem "processualista". De mesmo modo, o entender é composto, na visão dos quilombolas, por elementos que estão inscritos na paisagem e que podem ser apreendidos, sistematizados e encadeados na memória. Tal como advoga a abordagem de Alfred Gell, os quilombolas argumentam em seus discursos exegéticos sobre esta questão que, através da experiência e convivência de longa duração com os lugares, o entender pode ter uma existência apartada dos lugares e das relações onde foi produzido. Eventualmente, pode ser transmitido pelos relatos e narrativas e apreendido por aqueles extrativistas que possuem pré-requisitos para compreender e assimilar posteriormente na prática o que está sendo dito. tratada em detalhes neste artigo, mas, sem dúvida, é um tema de grande rendimento nas sociedades de tradição oral de modo geral e relativamente pouco tratado, principalmente na antropologia. Dentre os trabalhos que abordam o assunto em grande detalhe destaco a tese de doutorado em Antropologia de Cabral de Oliveira (2012) entre os Wajãpi do Amapá e a tese de doutorado em Etnobiologia de Couly (2009) sobre os ribeirinhos da Floresta Nacional do Tapajós no Pará. 
Desse modo, tentarei demonstrar com a descrição e a análise que, para meus interlocutores, os saberes assinalados pelo conceito de entender são compostos por estruturas e processos que são inseparáveis e que se informam mutuamente.

\section{ENTENDER}

Durante minha pesquisa de campo, meus interlocutores invariavelmente enfatizavam que somente se coleta castanha em escala comercial com sucesso em lugares onde se entende a mata (o local de trabalho) e/ou com quem entende. Quando um bom castanheiro diz que entende uma mata de castanhal, ele geralmente se refere a um conjunto circunscrito de pontas de castanha. Quando se faz esta afirmação no ramo castanheiro, isto quer dizer que se sabe detalhadamente em determinado espaço os melhores acessos às castanheiras, tanto por terra quanto por água; a localização precisa, a qualidade das amêndoas ea produtividade de muitas castanheiras específicas; os locais mais apropriados no entorno para a caça, a pesca e para a coleta de outras espécies vegetais; os detalhes sobre os tipos de vegetação e sobre as características de relevo e hidrografia das pontas de castanha; os nomes e as histórias associados às pontas de castanha e onde elas "começam ou terminam" em várias direções.

As pontas de castanha possuem como limites elementos muito diversificados, tais como cabeceiras, morros, baixas (como são conhecidas al gumas áreas de florestas sujeitas à inundação no tempo das chuvas), castanheiras e outras árvores específicas, estradas e caminhos ${ }^{6}$. Seus topônimos podem ser ou não estáveis e seus limites podem ser muito variáveis. Castanheiros diferentes que trabalham em uma mesma ponta podem delimitá-la de modo diverso e dar nomes diferentes para ela, de acordo com suas experiências particulares atreladas a este lugar.

Como já salientado, embora não seja algo isento de conflitos, atualmente no Alto Trombetas as matas de castanhal podem ser frequentadas livremente por qualquer habitante local. Entretanto, mesmo sem haver restrições formais de manejo e uso, o que ocorre na prática é que cada indivíduo, família ou grupo doméstico pratica o extrativismo comercial da castanha em fragmentos específicos do espaço territorial. Existem alguns fatores, que podem ou não estar conectados entre si, que direcionam o estabelecimento deste tipo de relação dos castanheiros com fragmentos específicos dos castanhais: o local de origem e de nascimento do indivíduo e de seus antepassados; a distância geográfica dos castanhais do local de habitação permanente; 0 estabelecimento de parcerias masculinas ao longo da vida; a capacidade individual exploratória e de descobrir novos lugares e, por fim, predileções de ordem espiritual.

A despeito destes fatores, o elemento mais importante que orienta esta forma de uso e de manejo dos castanhais, e que constitui o entender no ramo castanheiro, é a prática contínua e de longa duração das atividades constituintes do extrativismo comercial da castanha em fragmentos específicos dos castanhais. Para detalhar a

6 | Cabeceiras, na terminologia local, são cursos d'água interligados aos igarapés e, principalmente, aos lagos que podem adentrar quilômetros na floresta, em tipos de ambientes que localmente se denomina baixas. Na época das cheias seus cursos d'água correm na direção do interior da floresta e na vazante, época de verão, correm na direção das águas que as originam, principalmente as dos lagos. Cabeceiras, embora tenham cursos d'água definidos, diferem dos igarapés, pois elas não têm nascentes e não possuem seus cursos d'água em um único sentido. As cabeceiras podem, dependendo de sua extensão, ser de caráter ou sazonal-caso das pequenas, que existem somente na época das chuvas - ou permanentes caso das grandes cabeceiras. 
compreensão deste conceito, há primeiramente dois aspectos importantes que devem ser salientados sobre os saberes assinalados pelo entender. O primeiro é que eles precisam estar sempre se atualizando, pois como dizem os castanheiros, o mato está sempre mudando. O segundo, é que alguns destes saberes devem se manter restritos para ampliar o sucesso das atividades extrativistas e, assim, ajudar a manter os vínculos dos castanheiros com seus lugares de trabalho:

S.E.A.: (...) esse negócio de não levar em castanheira, a gente chama para isso, reservado. Isso veio desde o princípio. Veio, até os velhos que... e eles que tinham mesmo isso. É costume mesmo deles, olha eu tenho certeza que tem nego aí que já morreu, que eu conheci, que tem castanheira que nunca mostrou para ninguém, nunca na vida! Tem uns que ainda mostram para filho, mostravam. Desses agora que sabem, mas tinha deles, que não, não mostrava mesmo, de jeito nenhum! Onde ele ia numa castanheira, "já terminou a castanha", "já, está no vasculho, agora eu vou lá no meu reservado"; às vezes ele falava para a mulher, "olha, eu vou para tal lugar", às vezes, nem para a mulher. Ejá chegava com o paneiro cheio de castanha: "andando por aí, achei uma castanheira em tal lugar", não, ele já sabia daquela castanheira há muitos anos, deixou cair tudo pra ir lá buscar. Mas isso rolava muito entre os antigos...

A maneira mais eficaz e mais radical de se impedir a concorrência é dificultar que outras pessoas conheçam e tenham acesso a certos lugares onde se costuma trabalhar com a castanha. Quando muita gente passa a frequentar um lugar antes conhecido por poucas pessoas, se costuma dizer que estragaram olugar ou o lugar está estragado:

S.E.A: Seja para onde a gente conhece, mas aonde mais ou menos a gente calcula que a gente dá conta de andar, nós não fazemos caminho. E onde esse pessoal que vem de fora anda, ali perto do lago onde eu morava, tem um senhor que não é dali; você tinha gosto de andar na estrada dele. Tanto faz se em terra, como na água, sua canoa não esbarrava tanto no mato, só naqueles paus mesmo que tinha que esbarrar, mas era tudo limpo. Cabeceiras fundas assim, grandes; ele fazia as estradas, ele era o castanheiro lá. Eu ia lá no fim dela tranquilo. Enós daqui do Trombetas já não temos esse costume.

Para evitar que outros acessem alguns de seus pontos de trabalho, os extrativistas do Alto Trombetas desenvolveram diversas estratégias e habilidades que hoje em dia são cultivadas por todos aqueles que trabal ham com assiduidade no ramo castanheiro. Primeiramente, como salienta o depoimento acima, não são feitos caminhos ou trilhas demarcadas pela mata. O caminhar e o navegar devem ser sempre sutis: sem fazer muita zoada, cortando somente os galhos e o mato que realmente atrapalham a passagem. Isto implica em andar invariavelmente entre uma vegetação muito densa, o que requer os sentidos atentos com galhos que dificultam os deslocamentos, com os espinhos que podem causar ferimentos e com as formigas e insetos que picam. Quando se transita pelos igapós e igarapés pouco frequentados, costuma-se 
navegar com embarcações muito pequenas e instáveis pelo meio da vegetação submersa. O caminhar requer passos calculados e a velocidade da caminhada não aparenta ser o mais relevante. Mais importante é evitar quebrar galhos e alterar o menos possível o entorno. No caso do caminhar, com a ausência de trilhas demarcadas, muitas vezes são as castanheiras que ditam o percurso a ser feito. A ordem das castanheiras que serão visitadas pode ser diferente quando se coleta a castanha na mesma região mais de uma vez na safra. Este modo de locomoção e de coleta das amêndoas deixa poucos vestígios e torna difícil para aqueles que não conhecem e não possuem intimidade com os lugares em questão, descobrir os melhores acessos à determinada ponta de castanha e a localização das castanheiras mais produtivas e com amêndoas de melhor qualidade.

\section{ORIENTAÇÃO NOS CASTANHAIS}

No contexto do extrativismo onde imperam tais estratégias, habilidades e modos de relação com o ambiente, além dos conhecimentos sobre as castanheiras e sobre outros seres vivos que habitam os castanhais, dá-se muito valor, quando se fala em entender a mata, à capacidade de se orientar com perspicácia sem caminhos delimitados, de se locomover por atalhos e chegar de forma rápida e sem muito trabalho onde se necessita. O modo de orientação que utilizam para circularem nestes lugares sem o auxílio de caminhos ou trilhas delimitadas se torna possível pela percepção e interação com elementos muito diversificados que em alguns casos se apresentam sobrepostos entre si:

S.E.A: São as árvores, as pontas de terras, as bocas de cabeceiras; quantas cabeceiras a gente passa pra chegar no ponto que a gente quer, quantas pontas a gente passa pra chegar naquele lugar que a gente quer; inclusive, pra ali por onde nós vamos com o E., acontece isso com nós. Tem vezes que erramos, "mas nós passamos tantas cabeceiras, tantas pontas, a ponta tal, nós ainda não passamos, está pra frente..., é assim que nós fazemos. Boca de cabeceira é o que a gente mais usa, vamos conferindo as bocas das cabeceiras. Pelas enseadas, que a gente chama curva, vai conferindo e aí quando, por exemplo, passam três, quatro, "olha rapaz, já passamos as três pontas ou as três enseadas, já está próximo de onde a gente tem que chegar"; porque nós não temos costume, como o pessoal aí de fora que vem pra cá, pra esses nossos matos, eles têm o costume de cortar mato, fazer o caminho deles.

Quando circulam por onde entendem a mata, na maior parte das vezes, os bons castanheiros se locomovem por atalhos e planejam seus percursos de acordo com as árvores que querem visitar durante o dia, caso a atividade seja a coleta de castanha. Caso a atividade seja a caça ou a pesca, as referências dos percursos são as fruteiras e os ambientes preferidos das várias qualidades de animais caçados e pescados. $\mathrm{Na}$ 
coleta da castanha, a boa orientação na mata aperfeiçoa o trabalho e o torna mais eficaz em relação ao tempo, ao esforço e à produtividade.

O modo de orientação nas matas onde o castanheiro entende é fundamentado em duas premissas importantes do trabalho com a castanha e saber colocá-lo em prática em variadas situações é algo muito valorizado.

Primeiramente, ele auxilia no cumprimento da rotina e dos planejamentos durante a safra. A locomoção por atalhos permite executar as tarefas planejadas de forma mais rápida, mais objetiva e com menor esforço. Do mesmo modo, possibilita uma mudança de planos com a menor perda de tempo possível, caso o que foi planejado não possa ser executado. Um exemplo prático da virtude dessa habilidade pode ser vislumbrado quando um castanheiro vai à determinada ponta de castanha, distante de seu barraco ou moradia, esperando que os ouriços das castanheiras deste local já estejam no chão. Por alguma razão, ou porque os ouriços não amadureceram bem, ou porque alguém já os coletou, o castanheiro pode, portanto, não encontrar o que queria. Quando isso acontece, ele pode ir por via de atalhos para outra ponta de castanha e averiguar as árvores, sem perder o período ou o turno de trabalho. De mesma forma, isso vale para a navegação e a pescaria. Quando, por exemplo, se vai a uma fruteira e os peixes não estão aparecendo, é viável ir pelo uso de atalhos a outros pontos de pesca e aumentar a possibilidade de levar comida para casa. Em segundo lugar, quando executado com excelência, o modo de orientação na floresta contribui para garantir a exclusividade em certos locais de trabalho sem aumentar a necessidade de maior esforço, de gastar mais tempo e sem prejudicar a produtividade. Fazer bem o uso de atalhos e se movimentar sem caminhos delimitados não deixa indícios e, além disso, contribui para a diminuição do tempo de permanência na floresta o que, consequentemente, diminui o cansaço e a possibilidade de acontecer acidentes de trabalho.

Algo importante e, talvez, determinante, para este modo de orientação na mata, é o que alguns castanheiros chamam de "jeito da terra":

S.E.A: (...) conheço o jeito da terra; se eu fizer o cálculo que eu vou parar numa paragem e de repente eu varar em outra, já conheço o jeito da terra, já sei que eu não estou no lugar que eu queria ir. Já sei que não estou naquele lugar que eu queria ir; porque pra nós, por mais que nós conheçamos o mato, mas tem hora que a gente vacila. A gente confia que conhece e quando pensa que não, em um segundo a gente sai. Eu não sei se o senhor prestou atenção naquele dia que nós fomos no Jan. (ponta de castanha), que nós vínhamos vindo, aí o J. tombou um pouco pra lá da estrada e a vista já meio curta, estava meio escuro e a direção era aquela que eu vinha. De repente o ]. e o senhor entraram ali assim; aí nós andamos um pouquinho, aí eu parei, não sei se o senhor prestou atenção...aí eu olhei e disse, "não é pra cá a estrada; a estrada está pra ali", eu reconheci nos matos. Aí foi que nós dobramos e pegamos a estrada. 
No jeito da terra, incluem-se as árvores e tipos vegetais, as variações de relevo, os percursos dos cursos d'água, as estradas, os caminhos:

\footnotetext{
S.E.A: Eu já tenho variado ali para o rumo do S. (ponta de castanha) assim, para lá também não tem estrada, eu já tenho varado em paririzeiro (arvore frutífera) que eu chego lá, reconheço ele e aí eu já sei onde estou. Em caçada, você vê jabuti, a gente roda para cá, vai para ali e aí de repente eu dou uma tortubiada naquele sentido, "poxa, varei no paririzeiro tal"; lá tem o paririzeiro do Veado, que chamo, eu topei uma vez um veado lá, que a onça matou, lá no S. Eu já dei uma rodada por lá procurando jabuti, eu pensei que estava indo para lá para a frente e quando acabou, estava já voltando. De repente, varei nele e reconheci, "poxa, mas eu já estou no caminho de novo...". Porque nós, não sei se você já prestou a tenção, na castanheira essas coisas, no que chegamos no pé deles, é onde ol hamos logoé diretamente pra cima mesmo; tu olhou pra cima, pegou a posição da terra, se é na beira de uma baixa, se é no oiteiro, pronto, já está gravado.
}

Como se pode notar nos relatos, com o uso da expressão jeito da terra, os castanheiros destacam as variações ambientais percebidas como contrastes paisagísticos, assim como alguns elementos dos ambientes que se salientam pela percepção ou pelas experiências que tiveram nas relações com os lugares. Tais contrastes paisagísticos e elementos do ambiente, invariavelmente, funcionam como pontos de referência para a circulação e para a execução da atividade que se deseja no castanhal e são acionados de modo sobreposto ou não. O papel das árvores para saber o jeito da terra no modo de orientação dos extrativistas é algo que ainda não compreendi. No relato acima, o castanheiro explica que ele sempre olha para cima quando chega à base de uma grande árvore, o que parece revelar uma forma de cálculo por ele realizado para saber a posição da terra e o tipo de ambiente.

Um aspecto bastante destacado no trabalho com extrativismo, e também nas atividades de caça e pesca, é a possibilidade latente de se perder, mesmo que se entenda a mata. Alguns extrativistas têm alguns dizeres que enfatizam essa probabilidade: "o mato é bruto na hora dele" ou "sobre o mato, basta dizer que é mato, quem precisa dele já sabe". O mato por ser mato carrega consigo uma gama de possibilidades e, sem dúvida, uma das mais mencionadas é a possibilidade de se desorientar ou de se perder. Como comentou o castanheiro na penúltima narrativa, certa vez estava eu, ele e dois de seus filhos em uma das caminhadas buscando a castanha. Já era fim da tarde e andávamos por uma baixa que sabíamos de antemão ser imensa. 0 rapaz mais velho andava à frente e logo seu pai percebeu que estávamos adentrando nela e não saindo, como era de se esperar. O rapaz não desconhecia o lugar, mas se confundiu e tomou o rumo errado. Após a explicação didática, segundo o jeito da terra, de que estávamos na direção errada, disse o pai ao rapaz que caso continuássemos naquela direção, era certo que dormiríamos no mato, pois naquela baixa ele já havia andado muito e nunca tinha chegado ao fim dela no rumo onde estávamos indo. 
Perder-se ou se desorientar na mata também é algo influenciado por entes sobrenaturais como o curupira, o matinta pereira, as mães dos animais, bem como por seres monstruosos e com grande potencial de agressão aos humanos, como jiboias e/ ou as cobras grandes. Como também se observa em estudos etnográficos sobre outras populações da Amazônia, tais criaturas podem, pelo terror e por sua capacidade de ludibriar ou enganar os humanos, fazer com que extrativistas muito experientes fiquem reféns do medo e se percam na mata. Existem muitas histórias com esse tema no Alto Trombetas.

Certa vez, em uma conversa noturna, um velho castanheiro me relatou que estava trabal hando em uma mata central, distante dos lugares habitados e, no caminho de volta para o barraco, navegando por um extenso igapó, ele e seus parceiros se perderam. Perceberam isso de forma contundente quando começaram a andar em círculos e voltar sempre ao mesmo lugar. Isso aconteceu por várias vezes seguidas. Já era fim de dia e logo anoiteceu. Mesmo no escuro, não desistiram de tentar achar o caminho de volta. Continuaram navegando pelo igapó, área de floresta que fica submersa no período das chuvas, quando, de repente, ouviram uma "zoada muito feia", que vinha de um lugar não muito distante de onde estava o bote, a embarcação. Ficaram todos muito assustados e dois dos parceiros (estavam em quatro pessoas), tomados de medo, tentaram saltar na água para se dirigirem nadando à terra, mas foram dissuadidos pelo mais velho, que desconfiava ser a zoada obra da jiboia ou da cobra grande. Caso saltassem do bote, era certo que ela poderia comê-los, disse-me o velho castanheiro. Passaram algum tempo no bote, aterrorizados, pois a zoada era ininterrupta. Então, em determinado momento, o mais velho entre eles começou a falar de forma solene e calma. Disse se tratar da cobra grande e que a maneira que tinham de sobreviver e achar o caminho de volta era ficarem sem o medo e o mais tranquilo que pudessem. A fala do ancião ajudou acalmar a todos e logo a criatura foi embora. Desembarcaram em terra e passaram a noite na mata. Logo de manhãzinha, acharam facilmente o rumo do barraco. O velho castanheiro que me contou essa história disse que se não fosse a fala e a atitude do ancião, todos iriam se entregar, pois aterrorizados tentariam sair do bote e seriam devorados pela criatura.

Outro castanheiro contou-me que estava com um grupo de parceiros quebrando castanha também em uma mata central. No caminho de volta para o barraco, ainda em terra, perderam a localização do bote e, logo depois, começaram a ouvir uma grande zoada, vinda de vários lugares diferentes, parecida com paus quebrando e estralando. Mais uma vez, o mais velho extrativista da empreitada, disse se tratar do curupira e, para que não tivessem problemas, deveriam fazer um fogo bem alto. Como já estava escurecendo, deveriam passar a noite bem quietos e calmos, pois assim ela ou ele logo partiria.

Nas duas histórias é possível notar que há modos de livrar do infortúnio causado por tais criaturas: nunca ser dominado pelo medo, manter a cabeça fria, não 
tomar atitudes precipitadas e radicais e, se possível, recorrer a alguma oração que possa espantá-las. Dizem que a capacidade ou a virtude de tais criaturas nesse tipo de relação com os humanos se perde quando o medo e o susto desaparecem, tal como evidenciam os desfechos das histórias. Na maior parte das vezes, são os mais velhos, com mais experiência e vivência na mata, que conduzem as atitudes a serem tomadas e dirigem os outros a terem a conduta adequada para enfraquecer a capacidade de ação dos entes sobrenaturais agressores.

\section{O ENTENDER E A CONDUTA NAS MATAS}

Nos trabalhos na mata, especialmente no extrativismo comercial da castanha, entender ou não o espaço onde se trabalha é algo que define a conduta dos quilombolas na floresta:

Igor: Há quanto tempo o senhor estava sem andar por lá? (Me refiro a um lugar chamado "terra firme" de uma ponta de castanha específica)

S.E.A: Olha, eu cheguei lá estava com o que... uns oito anos que eu não ia lá. Eu gostava de ir lá, até quando eu estava criando meu filho S. sempre ia para lá. Mas assim, no vasculho, porque só saio do castanhal onde trabalho quando ele fracassa, que eu já estou vasculhando.

Igor: Depois a gente foi no Igarapé que divide (três pontas de castanha específicas) que pertence ao Igarapé do E.?

S.E.A: Isso, isso. Foi. Fomos no Igarapé que vai para o C., foi verdade, no segundo dia. Igor: Lá o senhor não entende muito né?

S.E.A: Não. Lá eu andei assim... nessa temporada que estou Ihe dizendo, tem uns oito anos, e tinha dois anos que eu não ia lá. Eu ia lá porque você sabe, a gente que trabalha no mato, nós somos curiosos, a gente não tem... a gente diz assim, o terçado leva, ele traz; porque a gente vai cortando; quando a gente vem, a gente vem por onde nós cortamos; e é por isso que eu ia, mas eu sabia que tinha castanheira para lá; eu não ia porque não tinha necessidade.

O assunto abordado nesta conversa se passou durante o período de cerca de dez dias em que acompanhei meu interlocutor em um vasculho, no ano de $2014^{7}$. Nesse referido ano a safra de castanha foi ruim e nos lugares onde esse castanheiro costuma trabalhar e que ele entende muito bem a mata, deu muito pouca castanha. Buscando uma maior produção ele adotou, no vasculho, a atitude de andar no entorno de seus locais de trabalho, em lugares que não lhe eram totalmente desconhecidos, mas que há algum tempo não frequentava. Nessa ocasião, pude perceber a diferença drástica de atitude e de comportamento entre quando se está em uma mata que se entende e em outra que não.

Em primeiro lugar, nas matas que ele não entendia, era clara a dificuldade de navegar pelos igapós e achar o porto do mato, modo como chamam o lugar correto de

7| Vasculho é o trabalho de coleta feito no final da safra, em lugares de acesso mais difícil ou distante dos lugares onde o castanheiro trabalhou durante a safra que dura um total de quatro meses aproximadamente. O trabalho de vasculho pode ser realizado buscando apenas algumas castanheiras específicas ou ir a pontas de castanha, geralmente de pequeno porte. A característica principal do vasculho é que a coleta é realizada em pequena quantidade; se a safra é boa, o resultado dessa coleta não é a comercialização, mas a castanha para comer durante o ano. Caso seja um ano de safra ruim, o vasculho adquire importância maior e é realizado com mais assiduidade e com fins estritamente comerciais. 
desembarcar em terra e adentrar na mata de um castanhal. Saber localizar o porto do mato é algo muito importante na coleta de castanha no Alto Trombetas e fazê -lo sem titubear é um sinal de que se entende muito bem uma mata. Para se achar o porto do mato é necessário saber de antemão os tipos de ambientes do entorno das castanheiras, para que se possa colocar o bote em lugar seguro e ter a certeza de que no percurso a ser realizado a pé não se topará com lugares alagados, onde não é possível atravessar. Por isso, é necessário saber a localização das cabeceiras, das baixas e de seus lugares alagados, assim como também dos lugares de terra firme, onde geralmente estão as castanheiras. Portanto, é fundamental possuir um saber ambiental/paisagístico elaborado para poder transitar nesses percursos de modo adequado. É preciso dizer que, muitas vezes, o desembarque no porto do mato não é exatamente nas imediações das pontas de castanha, sendo então necessário andar por longos trechos de baixas e de ribanceiras para chegar aos trechos de terra firme onde geralmente moram as castanheiras.

Em segundo lugar, ao contrário da desenvoltura e rapidez com que andava a pé nos lugares que entedia a mata, durante o vasculho, o castanheiro necessitou da ajuda do terçado, ou facão, e sentiu a necessidade de fazer trilhas demarcadas: "o terçado leva e o terçado traz". Nas pontas de castanha que ele sabia que havia alguns caminhos de acesso, houve a preocupação de encontrá-los como forma de se orientar e de se locomover com maior facilidade.

Por fim, outra diferença muito importante que pude notar diz respeito à extensão dos percursos realizados nas duas matas. Enquanto que nos lugares que entendia ele não tinha problemas em se dirigir ao rumo do centro ou em se distanciar dos cursos d'água, onde não entendia seus percursos eram sempre limitados pelos igarapés, cabeceiras e igapós. Em nenhum momento ele se distanciava das beiras de modo a não se desorientar. Um exemplo que ilustra de forma muito clara a diferença entre trabalhar em um lugar onde se entende a mata e em outro que não ocorreu em uma situação em que fomos a uma ponta de castanha onde, a partir da embarcação, estávamos próximos à beira, víamos perfeitamente as castanheiras, mas como não encontramos o porto do mato, mesmo estando tão perto, não conseguimos desembarcar em terra para ir até elas.

\section{OUTROS MODOS DE ORIENTAÇÃO NA FLORESTA}

Há também modos de orientação específicos para serem usados em matas que não se costuma frequentar. Eles são usados para tentar manter a discrição em empreendimentos denominados de exploração, como também para manter a exclusividade de circulação sobre lugares não muito frequentados e bem conhecidos, mas que possuem potencial para o extrativismo vegetal ou para a caça e/ou a pesca.

O que os extrativistas chamam de exploração é uma empreitada realizada através da formação de parcerias masculinas destinada exclusivamente a procurar 
com finalidade comercial gêneros vegetais em lugares pouco frequentados e distantes dos locais habitados. Ceralmente, denomina-se exploração as ocasiões em que ocorre tanto a avaliação das potencialidades de lugares ainda desconhecidos para fins extrativistas visando retornos posteriores, como também as expedições para busca imediata em locais distantes de tais gêneros vegetais alvos do extrativismo comercial. Ao contrário do modo de orientação nos lugares onde se entende a mata, em que o objetivo é se locomover por atalhos para a circulação rápida e precisa, nesse caso trata-se principalmente de tentar descobrir e explorar novos lugares sem deixar vestígios a outros extrativistas.

O primeiro modo de orientação usado nas matas que não se entende foi apresentado para mim por um velho extrativista como a "matemática do sol":

S.T.M.C: (...) porque hoje, essa natureza nós trabalhamos pelo sol, pelo sol. O Sol sai aqui, você pode marcar aqui, você vai até ele empinar, quando ele já estiver quase pro lado de empinar, você já vai marcando com o terçado, você marca a sombra dele, está aqui, assim; e quando é de tarde, aí vocêjá tem que vir de frente com ele e às vezes dobrando de frente com ele, pode vir de frente com ele... É o mesmo rumo, é. Quando você vai, você vai de frente com ele. Quando já é de tarde, você dobra [e] vem de frente com ele; todo tempo que você vem direto; e aí a través desse rumo, aí você vem tirando os gal hos, "tira o rumo tal", aí você vem, "cadê o Sol", "ah, está para cá"

Trata-se, como explicado acima, da orientação empreendida de acordo com as "posições do sol em relação à terra" e a um ponto de referência específico. Esse tipo de orientação funciona da seguinte maneira: quando escolhido um rumo, na partida para a mata, é observada a posição do sol e procura-se acompanhá-lo no decorrer do caminho. Assim, por exemplo, se a partida para a mata ocorre no amanhecer do dia e se está caminhando com os raios de sol batendo no peito (caminhada na direção oeste para leste), no fim do dia, no caminho de volta (que deve ser direção leste para oeste), o sol deve estar novamente batendo no peito, no rumo do poente. Quando se está dentro da mata e não é possível ver claramente a posição do sol em relação a terra, o terçado é colocado com a ponta para o solo e é observada a posição da sombra do cabo no chão. Dependendo do movimento da sombra (esse procedimento é feito várias vezes durante a caminhada), é possível saber, no decorrer do dia, mesmo no interior da floresta, a direção para onde estão se dirigindo os raios de sol e, assim, continuar seguro na caminhada. Nesse modo de orientação, também é importante ter em conta a direção de certos pontos de referência em relação à própria localização, como o rio Trombetas, alguma comunidade ou a mineração Rio do Norte. Desse modo, caso fique variado e seja necessário dormir na mata, no dia seguinte, sabendo a direção de um desses pontos, o extrativista pode reorientar-se e achar um caminho alternativo de volta. Outro recurso bastante usado a fim de evitar demarcar caminhos durante explorações é quebrar galhos pequeninos durante o caminho, 
apontando-os para o rumo do caminho de volta, seja do barraco, de casa ou para onde se quer retornar.

Existem também modos específicos de se orientar e de se locomover quando se deseja o deslocamento da beira - matas perto dos lugares habitados e dos cursos d'água conhecidos - para o centro - matas distantes dos lugares habitados e dos cursos d'água - ou vice-versa. A busca pelo centro, a partir da beira, é um procedimento importante no extrativismo comercial do óleo de copaíba (Copaifera langsdorffii), por exemplo. Quando se encontra copaibeiras na beira de um igarapé ou de uma cabecei$r a$, dizem que é certo, mesmo que elas desapareçam por algum tempo no caminho, que outras serão encontradas no rumo do centro, em lugares de terra firme. Na prática da exploração, muitas vezes descobrir o rumo do centro se torna um problema. Em muitas situações, é comum deduzir que o deslocamento está ocorrendo no rumo do centro e depois de horas de caminhada encontrar uma cabeceira ou uma grande baixa que indicam que a direção tomada foi errada. Uma das maneiras de ter certeza de que a caminhada está seguindo rumo ao centro é averiguar o curso de igarapés que foram encontrados no caminho, o que pode ser muito difícil, especialmente em lugares alagados onde a correnteza é quase imperceptível. As águas de um igarapé vão sempre em direção à beira, a um curso d'água maior, como um lago ou outro igarapé. Esse recurso é importante não somente para achar o rumo do centro, como também para voltar à beira, caso se fique perdido em uma mata central.

Por fim, existem modos de orientação específicos para a navegação e para a orientação nos igapós ou nos trechos de floresta alagados. Igapós, dependendo do lugar onde estão localizados, podem ser de grande extensão e, na ocasião de uma exploração, é possível se perder neles pela dificuldade de se conseguir encontrar a direção do leito da cabeceira ou do igarapé que o originou e pelo qual se estava navegando inicialmente. É necessário lembrar que as águas dos igarapés e das cabeceiras na época do inverno se estendem por muitos quilômetros fora do leito original, formando assim imensos igapós. De fato, é muito grande a possibilidade de se perder quando se distancia navegando pelos igapós dos leitos de uma cabeceira ou de um igarapé. Por esta razão, há de se ter nessas situações maneiras de encontrá-los ou de distinguir as águas dos trechos alagados que ficam próximos e distantes do curso original. O primeiro procedimento que deve ser feito quando se está nessa situação é observar a coloração da água. As águas das florestas alagadas distantes dos cursos originais dos igarapés ou cabeceiras são mais turvas e escuras pela concentração de matéria orgânica. O segundo é observar, geralmente com o uso do remo, a profundidade. Os leitos dos igarapés e das cabeceiras são sempre mais profundos do que os trechos de floresta alagada. O último é observar o movimento das águas. Quando se está próximo do curso original de um igarapé ou de uma cabeceira, as águas são mais movimentadas e seguem uma direção mais definida, daí a necessidade de seguir a direção do fluxo da água quando é possível percebê-lo. 
Por fim, uma peculiaridade específica dos igarapés, pois as cabeceiras se encontram sempre em ambientes de baixa, é a presença de matas de terra firme ou matas brutas, relativamente próximas ao curso original. Quando encontrados trechos de mata de terra firme é sinal de que se está próximo do leito de um igarapé.

Como foi possível notar, encontrar os leitos de cabeceiras e de igarapés quando se está perdido em igapós pode ser uma tarefa muito complicada. Pude testemunhar a necessidade de realizar tais procedimentos em uma exploração na busca da copaíba. Na ocasião, estávamos em um igapó muito extenso e queríamos encontrar um igarapé sobre o qual tínhamos a informação de que moravam muitas copaibeiras próximas ao seu leito. Passamos muitas horas, quase um dia todo, fazendo esses procedimentos: verificando a coloração, a profundidade, a direção da água e a presença de matas de terra firme, até encontrá-lo. Cabe lembrar que tais procedimentos são correntes no Alto Trombetas, pois na navegação não se corta o mato e o deslocamento é realizado com embarcações leves e pequenas para não deixar indícios de atalhos, dos melhores lugares de passagem e do rumo de aonde se pretende ir.

\section{APRENDIZADO E A ATUALIZAÇÃo DO ENTENDER}

A necessidade de atual ização do entender é sempre explicada pelos extrativistas com o argumento de que "o mato está sempre mudando". Os fatores que para os extrativistas ocasionam as mudanças importantes nos ambientes florestais são a intensidade e a quantidade de chuvas e de luz solar; as variações de temperatura nos diferentes períodos sazonais; a força dos ventos, o rebuliço das tempestades e as quedas das grandes árvores. Estes fatores, pelas mudanças ambientais que ocasionam, possibilitam o surgimento de muitas formas de vida diferentes que não existiam ou que não exerciam influência em determinado lugar. Esta dinâmica torna possível em pouco tempo mudanças importantes na composição florística e na paisagem das florestas. Nos castanhais, por exemplo, paus de folha de todos os tamanhos caem por variados motivos abrindo clareiras que possibilitam, pela maior incidência de luz solar, o nascimento e o desenvolvimento de tipos vegetais que não estavam presentes anteriormente no ambiente mais sombreado, como também o aparecimento de muitos tipos de animais que passam a morar ou a frequentar este espaço modificado, desencadeando, por sua vez, outras mudanças significativas. Um inverno com excesso de chuva ou um verão muito seco também mudam a vegetação e o solo de um ano para o outro. As próprias inundações anuais de áreas florestais, no tempo das chuvas, por si sós alteram a paisagem de determinado lugar no verão e no inverno seguintes. Extrativistas experientes argumentam que quando se passa mais de dois anos sem ir a determinado lugar que frequentaram com assiduidade, já não são capazes de se movimentar por atalhos e há a necessidade de se fazer camin hos com o auxílio do terçado. Portanto, sem a frequência e a relação contínua com os lugares, o entender vai perdendo sua plenitude. 
Além da constante necessidade de atualização, sempre existe para os extrativistas a possibilidade de desenvolver e ampliar o leque de lugares que entendem no decorrer da vida, especialmente a partir da descoberta de novos lugares com potencial para o extrativismo:

\footnotetext{
S.E.A: Só que tem várias castanheiras ali, várias mesmo. Eu descobri essa ponta de castanha correndo atrás de porcão na época que dava aqui. Eu fui lá pra outra paragem, aí topei um bando de porco lá no fim daquela cabeceira onde nós encostamos naquele dia; eu topei um bando lá e aí eu corri atrás deles, matei dois; mas lá já era muito longe; aí eu estava lá ajeitando eles, tirei os buchos, estava lá ajeitando, amarrando pra eu trazer, aí escutei a castanha cair, "pei", olhei, não vi castanheira, nada, "rapaz, a castanha caiu pra cá", aí eu saí naquele rumo...varei em uma castanheira, não tinha nada, "não foi aqui que caiu"; andei mais pra frente, a bicha estava bonita lá...aí comecei a andar por lá e fui descobrindo as castanheiras; quando foi ano passado nós fomos lá com o S.C.S.R. e ainda tiramos umas caixas lá; só que eu nunca andei toda a ponta.
}

Quando um extrativista descobre uma ponta de castanha, dependendo dos atributos das castanheiras, da facilidade de acesso, como também da ausência ou presença de indícios de que alguém a esteja frequentando, pode incluí-la entre seus lugares de trabalho. $O$ encontro com castanheiras de forma não planejada é muito mencionado por quem trabalha nessa atividade. Ceralmente, isso acontece quando ocorre a desorientação momentânea na mata ou quando se está caçando ou pescando. Isso pode acontecer tanto no tempo de castanha como fora da época de safra. Esse é um dos contextos em que se pode dar início à produção do entender em lugares com ocorrência de castanheiras que não se frequentava anteriormente.

Entender com plenitude um fragmento de castanhal é algo que demanda tempo. Como no caso contado acima, pode acontecer de alguém descobrir uma ponta de castanha e demorar muito tempo para percorrê-la em toda a sua extensão. Disse-me o castanheiro que acompanhei por mais tempo em minha pesquisa de campo que foram necessários cinco anos ininterruptos de trabalho durante praticamente toda a duração das safras de castanha (cerca de cinco meses/ano) para a aquisição do entender nos lugares onde trabalha atualmente. Argumentou que é possível adquirir conhecimento de forma satisfatória em um lugar sobre a localização das fruteiras e das castanheiras, sobre as configurações paisagísticas e adquirir a capacidade de se mover por via de atalhos em mais ou menos três anos seguidos de trabalho. Mais demorada, cerca de quatro ou cinco anos, é a aquisição dos saberes específicos sobre os indivíduos castanheiras, pois há conjuntos de pontas de castanha com centenas de árvores em perímetros às vezes muito extensos. Quanto mais se souber a respeito das castanheiras no âmbito individual, mais pleno será o entender e maior, portanto, a chance de se conseguir uma produção grande e de qualidade. 
É também possível, como já salientado, encontrar pontas de castanha e dar início ao entender com a prática da exploração. Portanto, além dos encontros não necessariamente intencionais, o início de uma relação com os lugares pode ocorrer durante uma atividade voltada para este objetivo específico:

S.S.T: (...) Nós vamos aqui, tirar uma castanha e de repente dá vontade da gente andar bem mais longe desse quadro que nós estamos acostumados a andar todos os dias; aí a gente tira o rumo, e dentro desse rumo, às vezes ele dá em cima de uma ponta de castanha que ninguém conhecia ali. (...) olha, até hoje tem vezes que nós achamos uma ponta de castanha lá que, castanha de todo ano está ali...

S.R.T: Olha, no Igarapé das A., nós entramos aí e todo mundo sabe que aí é uma castanheira que fica longe uma da outra. Nós fomos a trás de uma copaíba. Olha, subimos, demos uma volta lá, aí chegamos a té lá, "não é grande a ponta de castanha", já era tarde também, negócio de três horas da tarde, nós íamos em mais quatro, olha castanha está lá, amontoada, todo ano. Castanha graúda, nós trouxemos duas caixas, foi só o que a vasilha nossa aguentou e ficou de nós irmos lá, nunca mais achamos, a castanheira está lá; o S.C.T já rolou pra acertar e ainda não acertou!

Algo muito comum de acontecer nos encontros não intencionais e, igualmente, naqueles frutos da exploração, é encontraruma ponta de castanha e, posteriormente, tentar retornar ao lugar descoberto e não conseguir encontrá-lo. Existem muitas histórias, como a relatada acima, com esse enredo: o encontro com castanheiras, copaibeiras e árvores de breu e, na tentativa de retorno, não se conseguir achar o lugar novamente.

Esse fato recorrente revela uma característica muito importante do entender para os quilombolas. Ele necessita sempre estar gravado na cabeça. Pode, por isso, ser eventualmente transmitido através de relatos e explicações para aqueles extrativistas dotados de certos pressupostos que os possibilitarão decifrar o que está sendo transmitido. Ter também tais pressupostos gravados na cabeça é para os quilombolas fundamental para apreender o conteúdo dos relatos e narrativas. Quando se menciona a composição da paisagem, por exemplo, é necessário ter claro de antemão os elementos que definem e também os contrastes que diferenciam os diversos tipos de ambientes das águas e das florestas. Isto se adquire quando se inicia o trabalho no extrativismo, geralmente ainda na infância, acompanhando os mais velhos e experientes.

A transmissão do conhecimento pelos relatos e narrativas é particularmente importante na atividade de exploração. Quando um grupo de parceiros masculinos parte para uma exploração em busca de gêneros vegetais, é comum ter informações prévias, dadas de forma intencional ou não, adquiridas através de relatos ou explicações de outros extrativistas. A partir destes relatos, pode-se então com a relação direta com o ambiente encontrar os lugares mencionados e talvez concretizar a aquisição do entender. Com efeito, há de se dizer que a aquisição do conhecimento para os quilombolas não acontece exclusivamente pela prática e pela relação direta com o meio. Estes aspectos são de importância fundamental, como procurei demonstrar, 
mas, em parte das vezes, não atuam por si sós no processo de produção do conhecimento sobre os lugares.

Por fim, outros elementos evidenciados na narrativa anterior e que também são importantes para a aquisição do entender é a curiosidade e a aptidão exploratória. Essa qualidade é muito valorizada e não somente no extrativismo da castanha. Em outros tipos de extrativismo vegetal, como o da copaíba, em que a produtividade das árvores é limitada e demora a se renovar, a busca de novos lugares para encontrar novas árvores exige também tal aptidão. Existem alguns extrativistas que a possuem e, por isso, são muito reverenciados. Alguns gostam de praticar a exploração sozinhos ficando dias e dias andando e navegando pela mata, descobrindo lugares, caçando, pescando. Dizem que essas pessoas são as que entendem uma maior quantidade de lugares e as maiores extensões do espaço compreendido como território. Por isso, são muito procuradas para o firmamento de parcerias no ramo extrativista.

\section{CONSIDERAÇõ̃S FINAIS}

Para os quilombolas do Alto Trombetas, o entender deve ser continuamente atualizado pela prática e pelo convívio cotidiano com os lugares e também gravado na cabeça. Isto faz com que, na concepção dos meus interlocutores, entender simultaneamente se concretize e se atualize com a ação humana sobre o ambiente, como também, tenha uma existência autônoma em relação aos locais em que os saberes que assinala foram produzidos.

No que diz respeito ao debate antropológico sobre a relação entre processos/prática e mente/cognição nos modos de conhecer os ambientes, nota-se que, primeiramente, na teoria quilombola, o entender não muda de estatuto - de conhecimento para informação - quando ele se expressa fora dos contextos de ação e prática. Desse modo, os saberes por ele assinalados podem para os quilombolas ser transmitidos de forma integral fora dos locais onde são produzidos e atualizados.

Nesse sentido, o entender para os quilombolas se assemelha à parte dos argumentos de Alfred Cell (1985) sobre o conhecimento humano do espaço, tendo em vista as técnicas de navegação e de orientação dos marinheiros da Micronésia. Para o autor, o conhecimento do espaço, ou a conformação de um "mapa cognitivo" sobre uma região, é um conhecimento "não indexável", ou seja, não precisa estar situado no lugar onde foi produzido ou conectado diretamente à posição no mundo daquele que o produziu para existir ou adquirir veracidade. Segundo o autor, os marinheiros da Micronésia efetuam seus percursos entre as diversas ilhas de seu território através dos "cursos das estrelas"; as posições desses astros no céu que são referência para localizar determinadas ilhas. Desse modo, ao marinheiro é necessária a aquisição de um repertório adquirido com a prática da navegação, que 
associa a posição das estrelas à localização de lugares, algo parecido, portanto, com a maneira como funciona para os quilombolas em seus modos de orientação o jeito da terra. Tal como o curso das estrelas, o jeito da terra, assinala a associação entre os contrastes paisagísticos e as variações ambientais com a localização de lugares importantes para o ramo castanheiro. Os elementos assinalados pelo jeito da terra podem ser colocados em série, respeitando a posição inicial e onde se quer chegar. Assim, é necessário, para chegar a um determinado lugar, por exemplo, identificar e contar o número de cabeceiras, o número de baixas, passar por um "pé de serra, um oiteiro ou uma grande castanheira.

Por outro lado, pode-se observar convergências da teoria quilombola com aspectos importantes salientados pela análise processualista de Ingold. Como vimos, somente a execução por um longo tempo das atividades ligadas ao extrativismo é que permite que um castanheiro adquira com fluência e profundidade os saberes assinalados pelo entender. Isto exige a observação contínua e a conexão com os seres vivos habitantes das florestas e com as dinâmicas de transformação dos ambientes. Além disso, vimos também que é necessária do ponto de vista subjetivo a curiosidade, o ímpeto exploratório, a disposição de se conectar por longo tempo no espectro de relações de outros seres vivos e de dissolver nestes contextos as fronteiras com a natureza para compreendê-la de modo profundo.

De forma semelhante ao que argumenta a abordagem ingoldiana, para os quilombolas, o entender não assinala somente saberes fisicamente localizáveis que são alojados em categorias fixas de forma sistemática na memória e na cognição. Ele é constituído de forma processual e colocado em um movimento ininterrupto pela relação dos extrativistas entre si, com os lugares e com seres vivos nas florestas onde trabal ham. Estas relações dão vivacidade e continuidade no tempo e no espaço aos conhecimentos acumulados por gerações pelos quilombolas. Com efeito, seria, portanto, algo simplista afirmar que o entender esteja conformado somente de forma esquemática na mente, como um "mapa cognitivo". Ele se faz através dos sentimentos advindos das relações de longa duração com os lugares, pelas experiências subjetivas nos castanhais e pelas relações de parceria com outros extrativistas. De mesmo modo, se produz, se atualiza em um processo contínuo pela inscrição no corpo da conexão com o ambiente advinda da observação cotidiana, do manuseio correto dos artefatos e da execução com maestria das atividades constituintes do extrativismo comercial da castanha.

Todos estes elementos, mobilizados na produção e na atualização dos saberes evidenciados pelo conceito de entender, estão presentes nas vidas de todos os castanheiros. Eles atuam em conjunto e se revitalizam em confluência através das relações com os lugares, com os seres das florestas, com os entes sobrenaturais, e com outros castanheiros no espaço compreendido por esta população como seu território. 
Igor Alexandre Badolato Scaramuzzi é doutor em Antropologia Social pela Universidade Estadual de Campinas, desenvolvendo pesquisa sobre o extrativismo da castanha do Pará com ênfase nas relações e na produção e transmissão de conhecimentos sobre a Natureza na região do Alto Trombetas/Oriximiná/ Pará.

Contribuição de autoria: Não se aplica

\section{REFERÊNCIAS BIBLIOGRÁFICAS}

ACEVEDO, Rosa \& CASTRO, Edna. 1998. Negros de Trombetas: guardiães de matase rios. $2^{\text {a }}$ ed. Belém: Cejup/UFPA-NAEA.

ANDRADE, Lúcia M.M. de. 1995.

"Os quilombos da bacia do rio Trombetas: breve histórico". Revista de Antropologia, v. 38, n.1:79-99.

CABRAL DE OLIVEIRA, ].C. 2012. Entre plantas e palavras. Modos de constituição dos saberes entre os Wajãpi (AP). São Paulo, tese de Doutorado, Universidade de São Paulo.

COULY, Claire Couly. 2009. La biodiversité agricole et forestière des Ribeirinhos de la forêt nationale du Tapajós (Pará): usages, gestion et savoir. Tese de Doutorado em Etnobiologia, Muséum National d’Histoire Naturelle de Paris.

FUNES, E.A. 2009. "Mocambos:

Natureza, Cultura e Memória”. História Unisinos, v. 13 n.2: 147-153. 2007. "Comunidades Negras

- resistência e Africanidade na Amazônia Brasileira". Territórios e Fronteiras, v. 7: 47-72.
2004. "Mocambos do Trombetas:

História, memória e identidade". EA Virtual (Barcelona), Barcelona-Espanha, v. 1, n.1: 05-25. 1999. "Áreas das cabeceiras terra de remanescentes - Silêncio, Matá, Castanhaduba, Cuecé, Apui e São José". Boletim da Comissão Pró Índio, São Paulo, v. 1: 01-39. 1995. "Nasci nas matas nunca tive senhor: história e memória dos mocambos do Baixo Amazonas. São Paulo, tese de Doutorado, Universidade de São Paulo.

GELL, Alfred. 1985. "How to read a map: remark on the pratical logic navigation". Man, (NS) v.20: 271-286.

INGOLD, Tim. 2010. “Da transmissão de representações à educação da atenção". Educação, Porto Alegre, v. 33, n. 1: 6-25. 2005 "Jornada ao longo de um caminho de vida: mapas, descobridor-caminho e navegação". Religião e Sociedade, v.26, n.1: 76-110. 2000 The Perception of the Environment: Essays on Livelihood, Dwelling and Skill. London, Routledge. 
ARTICo | Igor Alexandre Badolato Scaramuzzi | Modos de orientação na floresta e as formas do entender no extrativismo comercial da castanha entre quilombolas do Alto Trombetas, Oriximiná/PA

RAMIREZ, Henri \& SHEPARD JR. Gleen. 2011. "Made in Brazil: Human Dispersal of the Brazil Nut (BEL) in Ancient Amazônia". Economic Botany, v.65, n.1: pp.44-65.
SCARAMUZZI, I. 2016. Extrativismo e as Relações com a Natureza em Comunidades Quilombolas do Rio Trombetas/Oriximiná/Pará. Campinas, tese de doutorado, Universidade Estadual de Campinas.

Recebido em 30 de maio de 2017. Aceito em 19 de março de 2019. 